\title{
A Study of Job Satisfaction among Civil Engineers Working in Hydropower Sector in Consulting Firms
}

\author{
Prabin Thapa ${ }^{1}$, Santosh Kumar Shrestha ${ }^{2}$ \\ ${ }^{1}$ Professional Network for Engineering Services Pvt. Ltd., Kathmandu, Nepal \\ ${ }^{2}$ Department of Civil Engineering, Pulchowk Campus, Institute of Engineering \\ Tribhuvan University, Kathmandu, Nepal \\ Corresponding author:er_prabin_thapa@yahoo.com and skshrestha@ioe.edu.np
}

Received: Sep 5, 2017 Revised: Dec, 29, $2017 \quad$ Accepted: Jan 3, 2018

\begin{abstract}
An increase in job satisfaction is directly related to an increase in productivity. The study was conducted with the aim of finding job satisfaction of civil engineers working in hydropower sector in consulting firms of Nepal. Descriptive cross sectional study was conducted among civil engineers in 34 consulting firms. Self-administered questionnaire were distributed among 230 civil engineers where 143 respondents had replied in time. Collected data was analyzed using descriptive as well as inferential statistical method. Study finding shows that on an average, the job satisfaction score of employees was 3.69 out of 5 with standard deviation of 0.63 coefficient of variance equals to 0.17 . Similarly, relationship of Job satisfaction by both method (single global rating method and summation job factors method) with independent variables shows that pay systems ( 0.424 and 0.642$)$, job itself $(0.334$ and 0.650$)$, relation with supervisors $(0.312$ and $0.637)$, working conditions $(0.296$ and 0.628$)$ and promotion opportunities $(0.273$ and 0.757 ) were positively related with overall job satisfaction at $95 \%$ confidence level. Based on finding of the study, it can be concluded that, the majorities of civil engineers were satisfied with their job despite their low rating on pay and promotion opportunities. The management of consulting firms and concerned authorities should focus on improving pay and promotions opportunities and designing proper programs for further improvement of job satisfaction.
\end{abstract}

Key Words: Productivity, correlation, single global rating, summation job factor method

\section{Introduction}

Every organization is made out of various human and non-human resources to accomplish particular goals. It is the human resources or the group of people that make project and organization success or failure. So, in course of developing any projects or organization, examination on employees' attitude towards their work assumes a huge part [2]. When people speak of employee attitudes, they usually mean job satisfaction, which describes a positive feeling about a job, resulting from an evaluation of its characteristics. A person with a high level of job satisfaction holds positive feelings about his or her job, while a person with a low level holds negative feelings [7]. Job 
satisfaction is defined as "a pleasurable or positive emotional state resulting from the appraisal of one's job or job experience" [5]. Also it can be defined as a favourableness or unfavorableness with which employees view their work [3].

Nepal has a huge hydropower potential. Unfortunately having more than hundred year's hydropower development history too, the electricity demand in Nepal is increasing by about $8-10 \%$ per year [4]. Bulk of the economically feasible generation has not been realized yet and we are still at the beginning stage of hydropower development. There is a long way to go ahead. Power shortage has been seen as a major barrier for gearing up Nepal's economic development process [1]. As the hydropower has a key role to play in Nepalese economy and civil engineers working in the hydro sector have a significant role requiring in large number in developing hydropower projects, the study has been done to know the civil engineer's general attitude towards their jobs and to provide suggestions for any improvement to the concerned parties.

Opinions of engineers about the suitability of work related variables such as nature of work itself, pay, promotion opportunities, employee relation with co-workers, behave of own supervisors and working conditions is of vital importance to be studied. The relation of job satisfaction with above mentioned factors will have significant role in exploring the current scenario between consulting firm and the engineers working with them and suggests for the necessary improvement ultimately promoting the hydropower project in the context of Nepal.

\section{Research Method}

The employee job satisfaction can be influenced by pay systems, nature of work he has been provided, promotion prospect, supervision, work group and working conditions [6]. One theoretical framework has been setup to carry out the study in which job satisfaction has been assumed as dependent variable and above mentioned factors as independent variables.

Job satisfaction was measured at a five point scale of 1 to 5,1 indicating highly dissatisfied and 5 indicating highly satisfied. A single question was asked to rate the response by the respondents to evaluate the job satisfaction directly by "Single Global Rating Method". For independent variables, six affirmative questions for each of the variables were asked. Response was measured at a five point scale of 1 to 5,1 indicating strongly disagree and 5 indicating strongly agree. Averages were calculated to access the response for each six variables. Then averages of all six variables were also taken to evaluate the job satisfaction indirectly by "Summation of Job Factors Method".

Questionnaires were distributed to all the civil engineers working in hydropower sector in 34 consulting firms of Nepal. Out of 230 questionnaires distributed to respective target group, 143 valid questionnaires were responded in time. The survey work was conducted for 2 months period starting from 26th August 2016 to 26th October 2016. Data collected using a questionnaire survey was analyzed through SPSS 20 and MS-Excel program.

\section{Result and Analysis}

\subsection{Demographic Characteristics}

Demographic characteristics of respondents are shown in Table 1 . There were $91.61 \%$ male and only $8.39 \%$ female civil engineers. Majority of them were between 26 to $35 \mathrm{yrs}$ of age (56.64\%) and were unmarried (60.14\%). $73.43 \%$ of the civil engineers were BE degree holders with most of them had office based job location $(72.03 \%)$. In regards to 
experience in the current firm, most of them lie in the category of $\geq 1$ to 5 years $(58.04 \%)$.

Table 1: Demographic Characteristics

\begin{tabular}{|c|c|c|c|}
\hline Demographic Variables & Categories & Frequency & Percentage $(\%)$ \\
\hline \multirow{2}{*}{ Gender } & Male & 131 & 91.61 \\
\hline & Female & 12 & 8.39 \\
\hline \multirow{5}{*}{ Age } & 25 yrs or less & 44 & 30.77 \\
\hline & 26 to $35 \mathrm{yrs}$ & 81 & 56.64 \\
\hline & 36 to $45 \mathrm{yrs}$ & 16 & 11.19 \\
\hline & 46 to $55 \mathrm{yrs}$ & 1 & 0.70 \\
\hline & Over 55 yrs & 1 & 0.70 \\
\hline \multirow{2}{*}{ Marital Status } & Married & 57 & 39.86 \\
\hline & Unmarried & 86 & 60.14 \\
\hline \multirow{3}{*}{ Academic Qualification } & $\mathrm{BE}$ & 105 & 73.43 \\
\hline & Master's Degree & 37 & 25.87 \\
\hline & Ph.D. Degree & 1 & 0.70 \\
\hline \multirow{2}{*}{ Job Location } & Office Based & 103 & 72.03 \\
\hline & Site Based & 40 & 27.97 \\
\hline \multirow{4}{*}{ Experience in current Firm } & $<1 \mathrm{yrs}$ & 39 & 27.27 \\
\hline & $\geq 1$ to $5 \mathrm{yrs}$ & 83 & 58.04 \\
\hline & $>5$ to $10 \mathrm{yrs}$ & 18 & 12.59 \\
\hline & $>10$ yrs & 3 & 2.10 \\
\hline \multirow{4}{*}{ Total Experience } & $<1 \mathrm{yrs}$ & 15 & 10.49 \\
\hline & $\geq 1$ to $5 \mathrm{yrs}$ & 78 & 54.55 \\
\hline & $>5$ to $10 \mathrm{yrs}$ & 33 & 23.08 \\
\hline & $>10$ yrs & 17 & 11.89 \\
\hline \multirow{5}{*}{ Annual Income (NRs.) } & $\leq 3$ lakhs & 48 & 33.57 \\
\hline & $>3$ to 6 lakhs & 61 & 42.66 \\
\hline & $>6$ to 9 lakhs & 20 & 13.99 \\
\hline & $>9$ to 12 lakhs & 9 & 6.29 \\
\hline & $>12$ lakhs & 5 & 3.50 \\
\hline \multirow{7}{*}{ No. of Dependents } & None & 58 & 40.56 \\
\hline & One & 13 & 9.09 \\
\hline & Two & 33 & 23.08 \\
\hline & Three & 21 & 14.69 \\
\hline & Four & 12 & 8.39 \\
\hline & Five & 3 & 2.10 \\
\hline & Six and above & 3 & 2.10 \\
\hline
\end{tabular}

\subsection{Measure of Level of Job Satisfaction and its Variables}

The weighted mean values were ascertained to measure the level of job satisfaction and its variables. The Table 2 shows that on an average the job satisfaction score in overall job location of employees was 3.69 out of 5 with standard deviation of 0.63 coefficient of variance equals to 0.17 . It indicates that on average employees were satisfied however the 
responses were varying by $17 \%$.

The job satisfaction was also measured by indirectly as summation job factors method (mean $=3.77$ ) which indicates that the level of satisfaction was little higher than measured by single global rating method (mean $=3.69$ ). Further most of employees preferred relation with work group as major parameter $($ mean $=4.33)$ followed by job itself $($ mean $=4.01)$, relation with supervisors $($ mean $=3.87)$, working conditions $($ mean $=3.87)$, promotion opportunities $($ mean $=3.54)$ and pay systems $($ mean $=3.15)$.

Table 2: Descriptive Statistics: Mean and Standard Deviation of Job Satisfaction

\begin{tabular}{cccccc}
\hline Variables & $\begin{array}{c}\text { Weighted } \\
\text { Mean }\end{array}$ & $\begin{array}{c}\text { Standard } \\
\text { Deviation }\end{array}$ & $\begin{array}{c}\text { Coeff. of } \\
\text { Variance }\end{array}$ & Skewness & Kurtosis \\
\hline $\begin{array}{c}\text { Job Satisfaction by single } \\
\text { global rating method }\end{array}$ & 3.69 & 0.63 & 0.17 & -0.645 & 0.599 \\
$\begin{array}{c}\text { Job Satisfaction by } \\
\text { summation job factors } \\
\text { method }\end{array}$ & 3.77 & 0.59 & 0.16 & -0.106 & -0.028 \\
$\begin{array}{c}\text { Relation with Work Group } \\
\text { Job Itself }\end{array}$ & 4.33 & 0.55 & 0.13 & -0.043 & -0.687 \\
Relation with supervisors & 4.01 & 0.61 & 0.15 & -0.191 & 0.372 \\
$\quad 3.87$ & 0.69 & 0.18 & 0.040 & -0.596 \\
Working conditions & 3.87 & 0.75 & 0.19 & -0.378 & 0.010 \\
Promotion Opportunities & 3.54 & 0.79 & 0.22 & -0.129 & -0.368 \\
Pay Systems & 3.15 & 0.78 & 0.25 & 0.011 & 0.175 \\
\hline
\end{tabular}

\subsection{Relationship of Engineers' Job Satisfaction}

In this subsection, we present the relationship of engineers' job satisfaction with job itself, pay systems, promotion opportunities, relation with supervisors, relation with work group and working condition perceived by engineers at their work.

Based on the Table 3, job satisfaction by single global rating method with independent variables shows that pay systems $(0.424)$, job itself $(0.334)$, relation with supervisors $(0.312)$, working conditions $(0.296)$ and promotion opportunities $(0.273)$ were positively related with overall job satisfaction whereas relation with work group (0.116) seemed to be statistically insignificant at $95 \%$ confidence level.

Table 3: Correlation of job satisfaction by single global rating method with independent variables

\begin{tabular}{|c|c|c|c|c|c|c|c|}
\hline $\begin{array}{c}\text { Pearson } \\
\text { Correlation }\end{array}$ & 흘 & 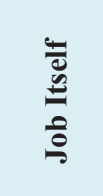 & 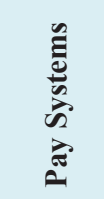 & 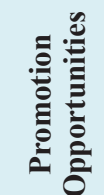 & 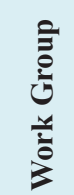 & 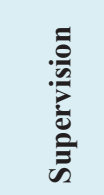 & 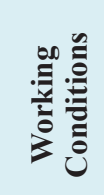 \\
\hline Job Satisfaction & 1 & $.334 * *$ & $.424 * *$ & $.273^{* *}$ & .116 & $.312^{* *}$ & $.296^{* *}$ \\
\hline
\end{tabular}


Based on the Table 4, job satisfaction by summation job factors method with independent variables shows that promotion opportunities $(0.757)$, job itself $(0.650)$, pay systems $(0.642)$, supervision (0.637), working conditions $(0.628)$ and work group $(0.536)$ were all positively related with job satisfaction and statistically significant at $95 \%$ confidence level.

Table 4: Correlation of job satisfaction by summation job factors method with independent variables

\begin{tabular}{|c|c|c|c|c|c|c|c|}
\hline $\begin{array}{l}\text { Pearson } \\
\text { Correlation }\end{array}$ & 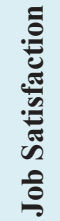 & $\begin{array}{l}\bar{y} \\
0 \\
0 \\
\overline{0}\end{array}$ & 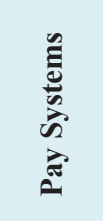 & 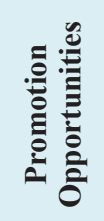 & 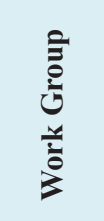 & 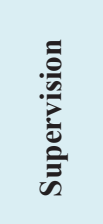 & 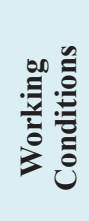 \\
\hline Job Satisfaction & 1 & $.650^{* *}$ & $.642 * *$ & $.757 * *$ & $.536^{* *}$ & $.637 * *$ & $.628 * *$ \\
\hline
\end{tabular}

\section{Conclusion}

The findings of this study indicate that job satisfaction among civil engineers working in hydropower sector in consulting firms of Nepal had positive attitudes and were satisfied with their job despite of their low rating on pay systems and promotion opportunities. The dominant sources of job satisfaction appear to be relation with work group, job itself, relation with supervisors and working conditions.

Pay systems and promotion policies in the consulting firms in Nepal need to be evaluated and improved periodically and in doing so, the consulting firms and concerned authorities (Government, Clients etc. involved in hydropower development) in Nepal should play a leading role. Hence, this work provides some sort of understanding about the job satisfaction level of civil engineers working in consulting firms of Nepal. Further research and investigation in such areas will certainly help in designing proper guidelines regarding the improvement of job satisfaction level of engineers and retaining them within the organization or nation to obtain higher productivity.

\section{References}

[1] Adhikari D (2006), Hydropower Development in Nepal. 18 art4 (Economic Review).

[2] Agrawal GR (2015), Organizational Behaviour in Nepal, 5th ed., Bhotahity, Kathmandu, Nepal: M. K. Publishers and Distributors.

[3] Davis K and Newstorm JW (1990), Human Behaviour at Work: Organisational Behaviour. New Delhi: Tata McGraw-Hill.

[4] DoED (2015), Annual Progress Report-2072. Kathmandu, Nepal: Department of Electricity Development.

[5] Locke EA (1976), The Nature and Cause of Job-satisfaction in MD Dunnette (ed.), Handbook of Industrial and Organisational Psychology. Chicago: Rand Mc Naaly.

[6] Luthans F (2010), Organizational Behaviour-An Evidence Based Approach; 12th ed., New York: Irwin, McGraw-Hill.

[7] Robbins S and Judge TA (2013), Organizational Behaviour; 15th ed., New Jersey: Prentice Hall. 